Investigaciones Fenomenológicas, vol. Monográfico 4/I (2013): Razón y vida, 297-312. e-ISSN: $1885-1088$

\title{
Why Declaring Ortega to Be a Phenomenologist IS IMPORTANT. REASONS AND DIfFICULTIES*
}

\author{
¿POR QUÉ ES IMPORTANTE CONSIDERAR A ORTEGA Y GASSET \\ FENOMENOLÓGO? RAZONES Y DIFICULTADES
}

\begin{abstract}
The debate about Ortega's relation to phenomenology has been continuous since the eighties of the last century. Before this date, Ortega's manifestations that he had abandoned phenomenology at the same moment he came to know it were understood literally, without scrutinising other manifestations of his that he had made on phenomenology, or that his philosophy is similar to that of Husserl's final works. Both manifestations seek to question the previous ones. The text clarifies first the meaning and importance of this polemic for Spanish philosophy, deeply influenced by that of Ortega's, and, secondly, I will set out what are the fundamental phenomenological concepts of Ortega's philosophy.
\end{abstract}

Key Words: Ortega y Gasset, Virtual Reality, Radical Reality, Philosophy.
Javier San Martín

Sociedad Española de Fenomenología /

UNED, España

jsan@fsof.uned.es

\begin{abstract}
Resumen: El debate sobre la relación de Ortega con la fenomenología ha sido continuo desde los años ochenta del siglo pasado. Antes de esta fecha, las manifestaciones de Ortega de que había abandonado la fenomenología en el mismo momento que la conoció, fueron tomadas al pie de la letra, sin examinar otras manifestaciones que había hecho sobre la fenomenología, o la de que su filosofía es similar a la de los últimos trabajos de Husserl. Ambas manifestaciones buscan cuestionar las anteriores. El texto aclara en primer lugar el significado y la importancia de esta polémica en la filosofía española, profundamente influenciada por la de Ortega, y, en segundo lugar, se expondré cuáles son los conceptos fenomenológicos fundamentales de la filosofía de Ortega.
\end{abstract}

Palabras clave: Ortega y Gasset, realidad virtual, realidad radical, filosofía.

First of all, I would like to thank the organizers for this opportunity to present one of the most important professional and vital contributions of my career in a forum as important as this one. I have committed myself professionally with this contribution, based on my conviction that I will thus make an important contribution, first, to clarifying this characteristic of 20th-century Spanish philosophy and, second, to clarifying a point of the phenomenological

\footnotetext{
* Translated by Nancy Kovalinka.
} 
movement or philosophy that could go unnoticed, or could fail to be considered with the precision made possible by Ortega y Gasset's philosophy.

When Lester Embree asked me to participate in the Dictionary of Phenomenological Aesthetics and I agreed to Dr. Rainer Sepp's proposal to write the entry on Ortega, I recall that L. Embree asked me wether Ortega was a phenomenologist and why. It was not an idle query; quite the opposite, it was a very pertinent one. Following the lines of international understanding, based mainly on what Ortega himself said and on what his most internationally known disciple claimed, Ortega had abandoned phenomenology as soon as he became familiar with it and, therefore, was distanced from it. Julián Marías' writings, as I found out in Saint Petersburg, had reached Hong Kong; one of the participants in our encounter there in 1997 told me so. And in these writings, the idea that Ortega had superseded phenomenology always appeared. This has been the general opinion that became part of the international conceptual map and that operated in Spain, as well, until the 1980s.

I say until the 1980 s because things changed then: we saw that all Ortega's statements in this respect are accompanied by a nuance that, if it is forgotten, leaves them disfigured. Because several notes must be made on this issue, and I will list them. First, the same Ortega who said that he had abandoned phenomenology as soon as he became familiar with it said, at the same time, that he had systematized phenomenology (IX, 1119) ${ }^{1}$. Second, and perhaps most important, there is something that usually goes unnoticed, and that is that this same Ortega said that his philosophy was similar to late Husserlian philosophy, to the philosophy that he had had the opportunity to read as soon as the first pages of The Crisis of European Sciences were published, even though Ortega attributed Husserl's late writing to Eugen Fink (VI, 29, fn), thus allowing for the conception that he had, up to this time, presented regarding phenomenology. Both facts, the first as well as the second, deserved a reflection that did not appear in Spain until the 1980s. In fact, I believe that the second point has not yet received the attention it deserves in Spain (or anywhere else), despite its decisive importance.

\footnotetext{
${ }^{1}$ Ortega y Gasset's Obras completas, Taurus, Madrid, 2004-2010, 10 vols. The roman number is the volumen of this Edition.
} 
At any rate, it must be said that this vision of an Ortega distant from and having gone beyond phenomenology had already been questioned in the USA in the 1970s. This occurred specifically in Oliver W. Holmes' book Human Reality and the Social World: Ortega's Philosophy of History (1975), which appeared even before Ortega's most clearly phenomenological book, the lessons on the System of Psychology, was published, with the unequivocal title of Psychological Investigations ${ }^{2}$. It also showed up in Robert O'Connor's article "Ortega's Reformulation of Husserlian Phenomenology," published in the journal Philosophy and Phenomenological Research in 1979, but which would have been submitted to the journal a year or two earlier, at least. After this, we know that Philip Silver wrote a worthy work that uncovered many phenomenological nuances in Ortega's work and considered his philosophy to be a worldly phenomenology, along the lines of the late Husserlian phenomenology.

In this paper, I will deal first with the general problems of this relation, its ambiguities and hidden nooks. Secondly, I will present the two aspects that come into play, the clarification of the kind of philosophy that is behind the foundation of 20th-century Spanish philosophy and the clarification of some important points of phenomenology, according to Ortega's contribution. Thirdly, I will focus on this contribution, so that, if I can manage it, Ortega's contribution on this point will be clear.

\section{The GENERAL PROBLEMS OF ORTEGA'S RELATIONSHIP With PHENOMENOLOGY}

With all the pages I have devoted to studying these problems since the 1980s (San Martín, 1994, 1998, 2012), I will not be adding anything new here, but I will at least try to provide a summary of what I believe to be the most important aspects. First, I would like to refer to a human characteristic that marks the problems in this relationship, described quite well by the American professor John Graham when he called it the can of worms $(1994,188)$ because, once opened, there is no closing it and discussing it is inconvenient and annoying. The fact that it is annoying can be deduced from the title I have

\footnotetext{
${ }^{2}$ First published by Paulino Garagorri in Revista de Occidente in Alianza Editorial, Madrid, 1982; Obras completas, vol. XII, Alianza Editorial, Madrid, 1983, pp. 331 ff. Now in Obras completas, Taurus, Madrid, 2007, vol. VII, pp. 429 ss.
} 
given this paper, which is a response to a question I was asked recently. The question was whether knowing if Ortega had been more or less influenced by Husserl mattered, because it might be irrelevant for understanding Ortega. Second, it is annoying, above all, because it forces us to interpret nuances in Ortega's most forceful expressions, which cannot then be taken literally. The personal aspect contained in this consideration is apparent in the not at all innocent questions that Graham throws out to Nel Rodríguez Rial, asking if he thinks that Ortega was lying to his readers when he said that he had gone beyond phenomenology and abandoned it (Graham, 385). And I am, of course, certain that it must be annoying for Julián Marías, whom I heard say (1982) that Husserl's only interesting work was Logical Investigations and who would, then, not be at all amused by my insistence on this subject. This is why it is a humanly disturbing issue. I would go so far as to say that it annoys those who are not within the orbit of phenomenology because they really do not care.

However, I perceive that a lot is at stake here. I feel that I must mention that, despite Ortega's self-positioning and the subsequent position of Julián Marías and Ortega's other most important disciple, Antonio Rodríguez Huéscar, regarding Ortega's phenomenology, both Julián Marías and the philosopher's own daughter, Soledad Ortega, participated in the inauguration of the first international congress on phenomenology that took place in Spain, in 1987, indicating that they subscribed to this movement. Something which is rather contradictory, considering the theses that Julián Marías defends; by being present, he was saying that what Ortega had done had gone beyond one interpretation of phenomenology, phenomenology interpreted according to the transcendental idealism of the 1913 Ideas. Husserl himself revised this interpretation, not because he changed the meaning of his phenomenology, but because he believed that the way he had reached to the public philosophical opinion was incorrect. This revision of expressions was a profound task for Husserl in the 1920s when he had to prepare a new edition of Ideas $I$.

\section{WhAT IS AT STAKE}

Anyone interested in Ortega can ask and does, in fact, wonder about the reason for this insistence on studying Ortega's links to phenomenology. Because another alternative is to just forget the subject, focus on the philosophy 
itself and operate philosophically on this basis. I have been asked this question more than once and so I think that this is an ideal venue for responding.

There are two ways of dealing with Ortega's philosophy, if we are convinced of its worth and that it is the origin, in a sense, of the most fertile Spanish philosophy of the 20th century, with all or most of this philosophy referring, in one way or another, to Ortegian philosophy. I say that there are two ways, because I will not discuss the despective way of dealing with this philosophy, the way that expells it to the terrain of mere literary essay with no philosophical implications. For both of these ways, to talk about Ortega is, to a certain extent, to talk about the beginning of the most representative Spanish philosophy of the 20th century. The School of Madrid depends on this philosophy, Xavier Zubiri belongs to the School of Madrid ${ }^{3}$, and thinkers such as Aranguren depend on him, with the enormous influence Aranguren has had; there is also the set of philosopher-physicians, such as Pedro Laín Entralgo ${ }^{4}$ and Juan Rof Carballo. The people who formed the so-called School of Barcelona are also very close to him, of course, independently of whether they felt personally closer to or more distant from Ortega. I am referring to Joaquín Xirau, Eduardo Nicol, and Ferrater Mora ${ }^{5}$.

So the first way of approaching Ortega's philosophy is the way Julián Marías does it, considering it to be an original philosophy that, in the flow of world philosophy, discovers radical life as the starting point of philosophy, attributing a historical reason that no one had discerned before to him. To the point that, with Ortega y Gasset, there is a new foundation of philosophy: Spanish philosophy seems to become a kind of new foundation for philosophy (Marías, 1991, 249) and, thus, has a nearly absolute originality, so original that we almost end up by ourselves. Because, without exaggerating, except for Ortega's philosophy and Julián Marías' philosophy, also in a limited sense, very little is known about this philosophy outside of our borders.

In contrast to this way of understanding Ortega, there is another way that seems more fruitful to me, assigning Ortega to one of the three great move-

\footnotetext{
3 About the "School of Madrid", see José Lasaga, "Die Madrider Schule", in J. San Martín (ed.) Phänomenologie in Spanien, ed. by J. San Martín, Koenigshausen \& Neumann, Würtzburg, 2005, pp. 281-283.

${ }^{4}$ See Diego Gracia, "Pedro Laín Entralgo", in J. San Martín, Phänomenologie in Spanien, op. cit., pp. 275-278.

${ }^{5}$ See Antoni Mora, "Phänomenologie im Exil (I) oder die Schule von Barcelona", in J. San Martín (ed.), Phänomenologie in Spanien, op. cit., pp. 288-290.
} 
ments that shape 20th-century philosophy: Marxist philosophy, phenomenological philosophy, and analytic philosophy. If Ortega belongs to the phenomenological movement, whatever the terms are, his work and philosophy will appear in the immense bibliography that makes up this movement. To this end, we must be clear on why he belongs to the phenomenological movement and we must clarify what is phenomenological in Ortega. So the importance of this issue is that, when we read Ortega, we are subscribing to a certain kind of philosophy, the kind that groups the best of 20th-century philosophy together, even though there are deep differences among the orientations. But we all know that Husserl and the early Heidegger, Scheler, Levinas, Merleau-Ponty, the early Sartre, Derrida, to a great extent, Patočka, Banfi, Enzo Paci, Dorion Cairn, Embree, Michel Henry, Ricoeur, Hanna Arendt, etc., are a set of names that make up a very substantial, even fundamental, part of 20th-century philosophy.

Having clear ideas in order to legitimately include Ortega's name in this cast not only is not banal or a useless contrivance, but means fighting for Spanish philosophy's contribution, both Ortega's as well as later philosophers' contributions, to this movement. This may be irrelevant for some, but it is not irrelevant in itself. Not doing it has already had consequences, consequences that we have suffered in our own country. By leaving Ortega outside of phenomenology, he was only included in a philosophy of life with both Nietzsche and Dilthey; this inevitably located him before phenomenology, making his philosophy one that, no matter how influential and important, belonged to the 19th century.

This was the first consequence in our own country. This is how all the candidates for secondary school teaching positions have studied Ortega's philosophy, due to this error in inclusion, (i.e. before Husserl and Heidegger). From this perspective, considering the time constraints for studying philosophy in secondary school, it was more important to explain Nietzsche than it was to explain Ortega. The result was a foregone conclusion until the 1980s: Ortega had disappeared from the philosophy syllabus in secondary school. If this seems unimportant from a professional perspective, it is because we are ignoring the value of education in political culture. If, on the contrary, Ortega is included in phenomenology, he will be placed after Husserl and Heidegger, and, at any rate, his texts can be used to introduce this movement that belongs fully 
to the 20th century. Students will be assigned parts of What Is Philosophy or of Man and People as a way of doing phenomenology and, therefore, as an introduction to a philosophy that transcends the 19th century.

These reasons may seem secondary, in a way, but I believe they are fundamental for fomenting the fertility of Ortega's philosophy. If it is done the first way, we already know how fertile it is: with no time for Ortega in secondary school, the immense majority of the students ended up not knowing anything about him. Later, at the university, Ortegian philosophy was not taught either, because the professors held the same opinion. So in the 1980s, Ortega had practicaly disappeared from philosophy in Spanish, not only in Spain but in all the Spanish-speaking world -with the possible exception of the United States, because there he was in the hands of Hispanists who presented him as the great Spanish writer that he is.

Consequently, and this is what I was getting to, Ortega's position in philosophy as a whole determines his fertility to a great extent. The first way has, de facto, neutralized this fertility because it led to including him in 20th-century philosophy of life that was the continuation of 19th-century philosophy. An author's fertility, in this case, Ortega's, does not in fact depend on the greater or lesser genius of his interpreters, but on whether or not his philosophy is widely read and discussed, starting in secondary school, where young people begin to shape the matrixes of their thinking. But in order to help shape these matrixes, secondary school teachers need to have studied the subject with great precision at the university; since this philosophy was not introduced, they can neither transmit it nor introduce it.

\section{THE MAIN CONCEPTS OF ORTEGA'S PHENOMENOLOGY}

Having presented the complexity and importance of Ortega's relationship with phenomenology, I will now try to present what I believe is most important in this philosophy in relation to phenomenology. In this respect, I think that Oliver W. Holmes' attitude deserves a special mention because in his book he forgets what we saw as fundamental: following the moments of this relationship, distinguishing early Ortega, in his "first navigation" (until 1930), from later Ortega, in his "second navigation", because Ortega's own statements in this regard are different. We have also had to distinguish between the conven- 
tional, published Husserl, and the so-called new Husserl who comes to light in the publications after Ortega's death, in order to justify our position; these publications showed a new side of Husserl, a side that Merleau-Ponty, Fink and Dorion Cairn had, as a matter of fact, understood. Holmes, who does not participate in these debates, does not have to overcome a fossilized opinion on this issue, but his vision of phenomenology comes from the texts on Intersubjectivity (volumes XIII, XIV and XV of the Husserliana) which he consulted, through the kindness of Iso Kern, the editor, before they were published (Holmes, 1975, $148, \mathrm{fn})$. He realized that the texts of the second-phase Ortega, the Ortega of the "second navigation", that is, the texts of Man and People, are consistent with this Husserl. He becomes aware that Ortega was right when he said that his philosophy was in the same orbit as, or was similar to, Husserl's philosophy from The Crisis of European Sciences, to the philosophy that is now the new Husserl. And so he takes Ortega's phenomenology from the "second navigation" for granted, ignoring Ortega's statements on this head.

Personally, I became acquainted with Ortega through Laín Entralgo ${ }^{6}$, when I had to read Ortega's criticism of Husserl in Man and People for my doctoral thesis. When I went back to this book in a more systematic way as a University teacher, I encountered two quite significant surprises. The first was that there was an introduction to phenomenological thought that seemed the best possible one for my students to get a good introduction to phenomenology. This happened in 1977, when I was explaining theory of knowledge in Santiago de Compostela and giving a seminar on Husserl's Cartesian Meditations. This first surprise marked me for life, and I have not changed my opinion. The second surprise, more astonishing, was that, in that text, I recognized the main substance of the doctoral course that I had had with Luis Cencillo in 1967/68. This course had impressed me at that moment because it represented, for me, a new language not only completely different from the language of Scholastics that I had been accustomed to until then, but also from the language of Sergio Rábade's Department, immersed in modern philosophy, both in his courses and in the subject of the theory of knowledge. Cencillo spoke of the world as being

\footnotetext{
${ }^{6}$ I no longer recall my first contact with Ortega in the doctoral courses of Prof. Cándido Cimadevilla (1924-1975), for which I wrote a paper on Ortega's and Unamuno's Quijotes. Unfortunately, I have no copy of this paper because at that time (1967) papers were handwritten and handed in to the professors and we did not keep copies. My first contact with Ortega left no mark on me because it was absolutely isolated.
} 
made up of pragmatic fields, in which things are tools, etc., ideas that are very familiar now but that were foreign to the philosophical environment of the Spanish university at that time.

With this biographical introduction to the subject, taking into account the moments and places -my impression in Santiago and Oliver Holmes' book, it is time to present the substance of Ortega's phenomenology. First of all, we find in Ortega's philosophy the turning point toward a philosophy beginning with the human being. He had formulated this in the Meditations on Quijote: everything comes to us under the form of individual life $(I, 755)$. This is the fundamental starting point of phenomenology, for which it is necessary to differentiate between the life world ("vital world", VII, 262 y 367; X, 175, 177, 185, 192, 193) and the cosmic world (VII, 321), and to consider that we are always in the life world, correlated with life, understood to be individual, flesh-and-blood life. This is, of course, independent from the philosopher's philosophical life; the philosopher must establish the philosophical life above the individual, flesh-andblood life as a "disinterested spectator" who must let go of his practical vital interests, even if only in a virtual fashion (VII, 366).

This starting point determines what I like to call the "phenomenological path of philosophy" that Ortega follows marvellously in his course What Is Philosophy. This course is conceived as a spiral itinerary (San Martín, 1998, 146 ff; 2012, $127 \mathrm{ff}$ ). First, the crisis situation is described, mainly the crisis of science, where people talk about practicing laboratory terrorism (VIII, 253). Second, it is a path that is traversed retrospectively, going back from the cosmic world to the area in which the world appears as a warmer environment. Therefore, one goes from the icy cosmic world to the warm intimacy of life. The second circle is devoted to exploring the kind of knowledge we are seeking, a knowledge that must be autonomous, because it depends on itself alone, and must also, secondly, be pantonomous, because it affects the whole of life. In order to comply with the first aspect, philosophy must proceed with self-evident statements, as evidence is the method of philosophy. In order to achieve this, philosophy must go through a narrow door, the door of epoché, or letting go ("desasimiento", this is the word Ortega uses [VII, 309], that is, "throwing away", "abandoning") of all previous beliefs, although there are beliefs such as belief in the existence of the world that can only be let go of in an as-if form, that is, virtually. 
At the third turn in the phenomenological path of philosophy, we enter into life itself, and this is what I really find sure or safe in my path to philosophy, but this life is not the solitary self, because the entire world -not the cosmic world, but the life world- accompanies it. The fourth turn is an analysis of this radical life, which is none other than the individual life that is the form of everything that is given to us. The fundamental characteristics of this life (and here is where Heidegger's influence shows up) are, first, to be known, therefore the consciousness that always goes along with it, or what makes it that particular life. The second characteristic is being in a world that precedes it, as a given, and the third is having to decide what to do, that is, shaping oneself as a life project. The phenomenological path of philosophy cannot be expressed in fewer words.

The third point, with more content, refers to Ortega's immense achievement in clarifying, long before Heidegger, the position of the phenomenology of perception. Ortega's advantage here is that he formulates his philosophy from a very specific intertextuality in which three aspects figure. First, there is a debate with Unamuno on the meaning of Europeanization as a political program that should be incorporated in Spain (San Martín, 1998, 17). Second, there is a conception, regarding this debate, about the philosophy of culture and therefore about the concept of culture. Third, there is a criticism of the neo-Kantian concept of culture as only higher culture, including science, morality, and art, which can lead to hiding the life that underlies this higher culture. So that before Kultur (German Kultur, with a K) there is a culture with a c, the ordinary culture that should be promoted. The Meditations on Quijote are devoted to studying this culture.

This is where Husserl's Göttingen lessons interfere especially, through Wilhelm Schapp, whose book Beiträge zur Phänomenologie der Wahnehmung Ortega used ${ }^{7}$. Taking into account that Schapp says, in his book, that he cannot say which explanations come from Husserl's suggestions (Schapp, 1981, IX), this work takes us into Husserl's lessons in 1907. In effect, there is a fundamental phrase in this work that appears in Husserl's texts: that there are three ways of being in the world, the two typically Cartesian ways, the res extensa

\footnotetext{
${ }^{7} \mathrm{~N}$. Orringer was the first to notice this connection. See Ortega y sus Fuentes germánicas, Ed. Gredos, Madrid, 1979, p. $134 \mathrm{ff}$.
} 
and the res cogitans, the cogito, but there is a third way that is neither the one nor the other, ideas, concepts, the way of seeing things, interpretation, perspective, meaning (see Husserl, 1984, 242; Schapp, 2 and 144). The prologue to Meditations on Quijote and the preliminary lesson are, to a great extent, devoted to presenting how meaning arises from sensation or in sensation, shaping the true reality that is human lived reality. There is a special phrase in Meditations on Quijote that only acquires its full meaning from this intertextuality and, without this intertextuality, loses most of its scope. After explaining the general plan of the book and the concept of culture as the result of an act that creates meaning, he asks the reader: "When will we open ourselves up to the conviction that the definitive being of the world is neither matter nor soul, it is no determinate thing, but rather a perspective" (I, 756).

In this sentence, which is a copy of one of Schapp's sentences which, in turn, repeats one of Husserl's 1907 sentences, what is important are the three terms: matter, soul, and perspective. The soul is the Cartesian res cogitans, and is therefore a substantialized understanding of consciousness. Matter is the res extensa and therefore a positivist-scientistic conception of reality. In contrast to these two terms, the being of the world is perspective, a way of being seen which essentially involves the subject, because it depends on the subject. Because of this, understanding the starting point of Ortega's philosophy depends, to a great extent, on a correct understanding of this sentence. In other languages, it will also depend on how the words are translated. In the Italian edition (translated by Bruno Arpaia, Guida editori, Napoli, 2000), soul has been translated as spirito (ob. cit., 43), a profoundly inadequate word, because spirit is, specifically in the German tradition, the opposite of soul, because spirit is the place of culture, the place of perspective. With this sentence, then, Ortega is proposing a theory of perception in which culture is the main ingredient, so things or a set of things, the life world, must be approached from culture, not only from animal life, from a theory of perception reduced to its animal elements, because human perception is always a cultural perception, which includes, or, even more than that, is made up of the animal part of the senses and the spiritual part of culture.

Because of this, perhaps Ortega's greatest contribution to phenomenology was to conceive the phenomenology of perception as a philosophy of culture, thus avoiding the objection that Heidegger later made regarding Husserl, that 
he introduced a theoretical interest into the discussion that destroyed or contaminated the object given in perception because perception is never a naturalistic perception but rather a cultural perception.

It is in this context of the presentation of phenomenology as a theory of culture that Ortega makes use of the concept "virtual", in both senses of the word, offering an entire theory of virtuality that was far ahead of its time; this is quite relevant today, as it allows us to focus the new world that has arisen with the new technologies with a theoretical basis that other theoretical lines do not have.

Within the concept of virtual, Ortega includes, first, the idea which we use to complement sensations to give us things and the world. Next, he includes the concept with which we add to perception and which gives us the limits of things, and then the world behind the world, in which we always see the world, or the other sides of the things that allow us to see whole things, not just bits of things. Finally, there is meaning or sense, the word Ortega uses instead of the word concept, due to its murky tradition (Ortega, VII, 487).

Virtual, on the other hand, has two sides. On one hand, it is a kind of as-if reality, taking into account what is a virtual reality in sight, a pure phantom with no real consistency. But that which is virtual also has strength, because it comes from virtus, from that in virtue of which something is done. Because a project is something virtual, a mere projection of the imagination, but it has the virtue of producing or motivating the behaviours that lead to carrying out the project. It is precisely in the duality of what can be perceived by senses, mainly by touch, and what is virtual, what is targeted by sight, because what is virtual is fundamentally what is imagined visually, that we have the two sides of the world, the side of what is patent and the side of what is latent, which gives meaning to the patent world because what is patent only exists as it does thanks to what is latent. Perception is only what it is because of the interpretation it is inserted into, in which language has a very important role, if not an absolutely decisive one, because language is what really establishes the limits. But life projects also have a fundamental role, to the point that the world we live in, which is none other than the life world, is a world made up of our projects, and things take or acquire consistency only from these projects, because they are utensils, tools, infrastructures for our projects, etc. 
I like to use Magritte's paintings to think of Ortega's philosophy. In Magritte's paintings, we can follow the play of the representation of what is real and the representation of what is pictoric-virtual, in really delightful reduplicating mirrors. There is no one like Magritte in the 20th century who has managed to plastically show that which represents the virtual part of the perception, and that which means the real one.

To finish my talk, I will quote what I consider to be the correct approach to Ortega's philosophy, as philosophy in general, but also affecting this philosophy as phenomenology. I am referring to the practical function of philosophy. When we say that phenomenology is an exponent of life (Fink, 1988, 44, 65), it does not mean that it is an exponent only or even mainly from a theoretical perspective. The structure of life is not primarily and principally focused on knowing but on doing. The three verbs that define the structure of life are knowing, valuing, and doing. Both knowing and valuing depend on doing because, as Ortega saw quite clearly in What Is Philosophy, the characteristic of human life is to be known and to decide, to decide what to do. Life is a project, a tendency to selfpreservation, as Husserl would say (Sepp, 1997), in one's own self which, on the other hand, is a "deferred" self (Heidegger), because the being about which or for which we worry is the one that we are not and would like to be. This structural tendency that resides in, defines, or determines human life causes philosophy not to be autonomous but to serve this life. This is what we can summarize by saying that philosophy is integrated in a structure in which theory is a function of praxis.

This kind of axiom of life remained relatively hidden in Husserl's phenomenology, at least in its earlier public manifestation, due to the weight that the first theoretical clarification had in it, mainly, in the first place, as a refutation of psychologism in the Logical Investigations and, later, in the presentation of phenomenology in Ideas. Ortega is aware of the privileged situation and relative isolation in which the learned people (the German Gelehrte) lived because they had no problems (IX, 163). For a Spanish person, on the contrary, everthing is a problem. When Ortega went from Leipzig to Berlin to study during the winter semester of 1905, already with a good knowledge of German, he realized that the library of the University of Berlin had all the materials he needed to study, that there, shall we say, he could be a complete professional; 
for a Spanish philosopher, the first problem was not a philosophical one but the general problem of his own country, Spain.

This different starting point was fundamental in the difference between his approach and Husserl's. While Husserl needed everything to fall apart around him with World War I in order to become aware that philosophy's goal was, above all, to decide how to orient action, this starting point is at the origin of philosophy itself for Ortega. This is why the Spanish philosopher Pedro Cerezo, a masterful interpreter of Ortega said, years ago, that Ortegian philosophy is "fundamentally, I mean in its root and inspiration, practical reason" (2011, $366)$, because "his metaphysics of vital reason has arisen from this practical/ethical attitude."

It is true that there are important changes in Ortega's orientation following how his thinking evolves, but they are all determined by his desire to manage to safe the situation, that is, to give the things full meaning by fulfilling them. This task is an act of love, because that is what love is, leading that which is loved to perfection. And if Spain was the problem, there was no other philosophy than a philosophy oriented to saving Spain. World War I, which was decisive in reorienting Husserl's thinking, from theory to practice, was also decisive for Ortega in a different direction, not from theory to practice -he already had this orientation- but to change his attention from Spain to Europe. The Great War had shown that the evils of Modernity were deeper than they seemed and therefore the saying of the Spanish regenerationists, who had diagnosed Spain as the problem, had to be altered, making Europe the true problem.

From this moment on, Ortega focused on European problems, devoting himself, in a very similar way to Husserl, to scrutinizing the evils of Modernity and of the scientific spirit it left as its inheritance. The most brilliant moments of this Ortega, which coincide with what he called the "second navigation", or at least with the edge of this period of his philosophical life, depend on the consideration of the problems of Europe, as can be seen in Chapter XV of his book The Revolt of the Masses, or in his diagnosis of the crisis of the belief in reason -with the earlier preparation of the theory of Ideas and Beliefs - in the mid1930s (in En torno a Galileo, VI, $371 \mathrm{ff}$ ), or with the "Notes on thought, on its theurgy and its demiurgy" from 1941, in which he echoes the relationship of phenomenology with history, or in his conference "De Europa meditatio quaedam," in 1949. The objective of these texts is none other than to orient political 
action toward the reconstruction of Europe as our only chance to continue to offer the world what we had offered up to then, the commandments, that is, to continue offering the world principles of public opinion for directing moral and political action. The fact that Ortega talks about the "commandments" [mandamientos] indicates that they are not mere norms of political organization but also true moral norms because political action cannot be disconnected from moral norms.

So what had appeared in the second period of Husserl's phenomenology, because they were reflections that remained unedited for the most part, was not effective, and the previous theory continued to predominate, to the point that phenomenology came to be identified with pure theory. In Ortega, on the contrary, the practical function appears right from the start, so that such a philosophy is at the very origin of his reflection in the front line. This contribution Ortega's is truly enlightening and exemplary for the phenomenological movement.

I hope, with these considerations, to have summarized the place that Ortega holds and should hold in 20th-century philosophy.

\section{BIBLIOGRAPHY}

CEREZO, Pedro, José Ortega y Gasset y la razón práctica, Biblioteca Nueva/Fundación Ortega y Gasset-Gregorio Marañón, Madrid, 2011.

FINK, Eugen, VI. cartesianische Meditation, Teil 1. Die Idee einer transzendentalen Methodenlehre, ed. by Ebeling, H., Holl, J., and Van Kerkhoven, G., Kluwer Academic Publishers, Dordrecht, 1988.

GRAHAM, John, A Pragmatist Philosophy of Life in Ortega y Gasset, University of Missouri Press, Columbia, 1994.

HOLMS, Oliver W., Human Reality and the Social World: Ortega's Philosophy of History. University of Massachusetts Press, Amherst, 1975.

HUSSERL, Edmund, Einleitung in die Logik und Erkenntnistheorie. Vorlesungen 1906/07, Hua XXIV, edited by U. Melle, M. Nijhoff, The Haag, 1984.

MARÍAS, Julián, Acerca de Ortega, Espasa Calpe, Madrid, 1991.

O'CONNOR'S, Robert, "Ortega's Reformulation of Husserlian Phenomenology", in Philosophy and Phenomenological Research, 1979

ORRINGER, Nelson, Ortega y sus fuentes germánicas, Madrid, Editorial Gredos. 1979.

ORTEGA Y GASSET, José, Obras completas, Madrid, Alianza Editorial, 12 volumes, 1883.

- Obras Completas, 10 volumes, Taurus /Fundación Ortega y Gasset, Madrid, 2004-2010. 
SAN MARTÍN, Javier, Ensayos sobre Ortega. UNED, Madrid, 1994.

- Fenomenología y cultura en Ortega, Editorial Tecnos. Madrid 1998.

- La fenomenología de Ortega y Gasset, Biblioteca Nueva, Madrid, 2012.

- (ed.) Phänomenologie in Spanien, Koenigshausen \& Neumann, Würzburg, 2005.

SCHAPP, Wilhelm, Beiträge zur Phänomenologie der Wahrnehmung, Halle, Max Niemeyer, , Vittorio Klostermann, Frankfurt, ${ }^{4} 2004$, reprint of the first edition of 1910.

SEPP, Hans Rainer, Praxis und Theoria, Husserl transzendentalphänomenologische Rekonstruktion des Lebens. Verlag Karl Alber, Freiburg i. B., 1997

SILVER, Philip, Ortega as phenomenologist: The Genesis of "Meditations on Quixote", Columbia University Press, New York, 1978. 